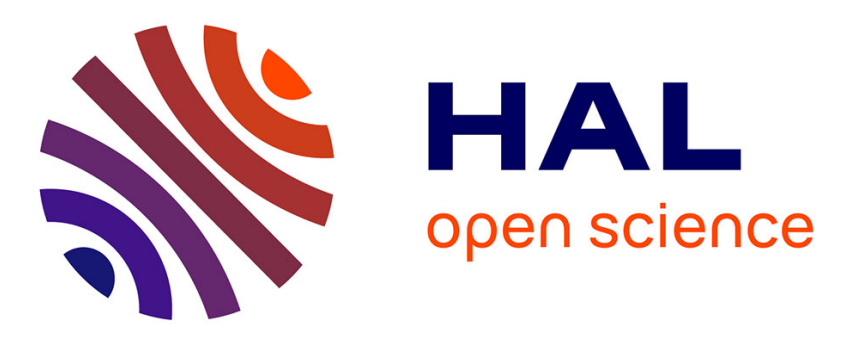

\title{
Aminofluoroalkoxide amido and boryloxo lead(ii) complexes
}

Adrian-Alexandru Someşan, Thierry Roisnel, Vincent Dorcet, Cristian Silvestru, Yann Sarazin

\section{- To cite this version:}

Adrian-Alexandru Someşan, Thierry Roisnel, Vincent Dorcet, Cristian Silvestru, Yann Sarazin. Aminofluoroalkoxide amido and boryloxo lead(ii) complexes. Dalton Transactions, 2019, 48 (27), pp.9944-9948. 10.1039/c9dt02110h . hal-02179649

\section{HAL Id: hal-02179649 \\ https://hal-univ-rennes1.archives-ouvertes.fr/hal-02179649}

Submitted on 23 Sep 2019

HAL is a multi-disciplinary open access archive for the deposit and dissemination of scientific research documents, whether they are published or not. The documents may come from teaching and research institutions in France or abroad, or from public or private research centers.
L'archive ouverte pluridisciplinaire HAL, est destinée au dépôt et à la diffusion de documents scientifiques de niveau recherche, publiés ou non, émanant des établissements d'enseignement et de recherche français ou étrangers, des laboratoires publics ou privés. 


\title{
Aminofluoroalkoxide amido and boryloxo lead(II) complexes $\$ \ddagger$
}

\author{
Adrian-Alexandru Someșan, ${ }^{\text {a }}$ Thierry Roisnel, ${ }^{\mathrm{b}}$ Vincent Dorcet, ${ }^{\mathrm{b}}$ Cristian Silvestru ${ }^{* a}$ and Yann \\ Sarazin $* b$
}

\begin{abstract}
We report here on the utilisation of a readily available bidentate aminofluoroalkoxide in lead(II) chemistry. Stable heteroleptic three-coordinate complexes can be produced in high yields, including a convenient amido synthetic precursor and a rare case of Pb"-boryloxide.
\end{abstract}

Known for 6000 years, lead is a versatile metal that has been used in water pipes by Romans owing to its malleability and resistance against corrosion and, closer to us, as an anti-knock agent in petrol and as a paint additive. However, it is a highly toxic element, and its use for industrial purposes is now essentially prohibited. ${ }^{1}$ In spite of its historical significance, the organometallic chemistry of lead, and in particular that of divalent lead, has been rather overlooked. Investigations on structural features in lead(II) complexes were until about 10 years ago restricted to multidentate ligands, ${ }^{1-2}$ and stable twoor three-coordinate lead(II) complexes were scarce. More recently, the utilisation of ubiquitous $\beta$-diketiminates has enabled the groups of Fulton ${ }^{3-11}$ and a few others ${ }^{12-15}$ to obtain a variety of three-coordinate lead(II) complexes (e.g. halides, amides and anilides, alkoxides and aryloxides, alkyls, phosphides), and our understanding of the reactivity of these species has improved accordingly. We have on our side used $\left\{\mathrm{N}^{\wedge} \mathrm{O}^{\wedge} \mathrm{E}\right\}^{-}$organochalcogenolates for the preparation of heteroleptic lead(II) amides. ${ }^{16}$ We have also shown that $\left[\mathrm{Pb}^{\prime \prime}\right]$ boryloxides could be obtained as the two-coordinate $\left[\mathrm{Pb}\left(\mathrm{OB}\left\{\mathrm{CH}\left(\mathrm{SiMe}_{3}\right)_{2}\right\}_{2}\right)_{2}\right]$ or as the three-coordinate $[\{2-$ $\left.\left.\mathrm{Me}_{2} \mathrm{NCH}_{2} \mathrm{C}_{6} \mathrm{H}_{4}\right\} \mathrm{PbOB}\left\{\mathrm{CH}\left(\mathrm{SiMe}_{3}\right)_{2}\right\}_{2}\right]$ bearing a bidentate organoligand. ${ }^{17}$ Yet, beyond $\beta$-diketiminates ${ }^{3-15}$ and bulky terphenyls, ${ }^{18-20}$ the number of ligands suited to the design of

\footnotetext{
a. Supramolecular Organic and Organometallic Chemistry Centre,

Chemistry Department, Faculty of Chemistry and Chemical Engineering,

Babes-Bolyai University, RO-400028 Cluj-Napoca, Romania.

E-mail: cristian.silvestru@ubbcluj.ro; Tel: (+40) 264-593833.

b Univ Rennes, CNRS, ISCR (Institut des Sciences Chimiques de Rennes) - UMR 6226,

F-35000 Rennes, France.

E-mail: yann.sarazin@univ-rennes1.fr; Tel: (+33) 223233019.

+Electronic Supplementary Information (ESI) available: Synthetic details; NMR and crystallographic data. See DOI: 10.1039/x0xx00000x
}

heteroleptic low coordinate lead(II) complexes remains limited.21-25 In particular, the implementation of potentially bidentate alkoxides for the preparation of soluble heteroleptic lead(II) species only includes a handful of examples, ${ }^{16,24,26}$ even if homoleptic $\left[\mathrm{Pb}(\mathrm{OR})_{2}\right]_{n}$ and $\left[\mathrm{Pb}\left(\mu_{2}-\mathrm{OR}\right) \mathrm{N}\left(\mathrm{SiMe}_{3}\right)_{2}\right]_{2}$ alkoxides have been known for some time. ${ }^{27-29}$ We report here on the preparation of a readily available aminofluoroalkoxide that enables the facile synthesis of stable three-coordinate lead(II)

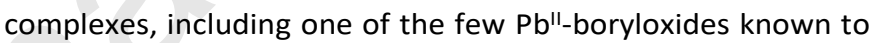
date. The bidentate ligand was chosen on account of the low bridging ability of its alkoxide, due to the positioning of electron-withdrawing $\mathrm{CF}_{3}$ groups in $\alpha$ position. ${ }^{30}$ The synthetic and structural features of these complexes are presented.

The aminofluoroalcohol 2- $\mathrm{Et}_{2} \mathrm{NCH}_{2} \mathrm{C}\left(\mathrm{CF}_{3}\right)_{2} \mathrm{OH}$ (aka $\left\{\mathrm{RO} \mathrm{F}^{\mathrm{F}} \mathrm{H}\right.$ ) was prepared in $90 \%$ yield upon stoichiometric reaction of $\mathrm{HNEt}_{2}$ with 2,2-bis(trifluoromethyl)oxirane in $\mathrm{Et}_{2} \mathrm{O}$ (Scheme 1). ${ }^{31}$ The proligand was isolated as a colourless, volatile liquid. The formulation was confirmed by NMR spectroscopy in benzene- $d_{6}$ and HR-MS spectrometry, and bulk purity was further confirmed by combustion analysis. Notably, the ${ }^{19} \mathrm{~F} N M R$ spectrum exhibits a sharp singlet at $\delta_{19 \mathrm{~F}}-77.8 \mathrm{ppm}$, while the ${ }^{13} \mathrm{C}\left\{{ }^{1} \mathrm{H}\right\}$ spectrum features a quartet centred on $\delta_{13 \mathrm{C}} 124.4 \mathrm{ppm}$ $\left({ }^{1} J_{\mathrm{CF}}=287 \mathrm{~Hz}\right)$ and a septet at $\delta_{13 \mathrm{C}} 71.8 \mathrm{ppm}\left({ }^{2} J_{\mathrm{CF}}=29 \mathrm{~Hz}\right)$. All resonances are sharp and well resolved in the ${ }^{1} \mathrm{H}$ NMR spectrum.

The reaction of $\left[\mathrm{Pb}\left\{\mathrm{N}\left(\mathrm{SiMe}_{3}\right)_{2}\right\}_{2}\right]$ with one equivalent of $\{R O F\} \mathrm{H}$ afforded the heteroleptic, mononuclear amido complex $\left[\left\{\mathrm{RO}^{\mathrm{F}}\right\} \mathrm{PbN}\left(\mathrm{SiMe}_{3}\right)_{2}\right](\mathbf{1})$ in good yields, ca. $75-80 \%$, and with excellent reproducibility. Complex $\mathbf{1}$ was isolated as a pale yellow crystalline solid that displays good solubility in all common organic solvents, including aliphatic hydrocarbons. It is a rare occurrence of heteroleptic alkoxide/amide lead(II) species. ${ }^{16,26,29}$ Single crystals of $\mathbf{1}$ suitable for X-ray diffraction

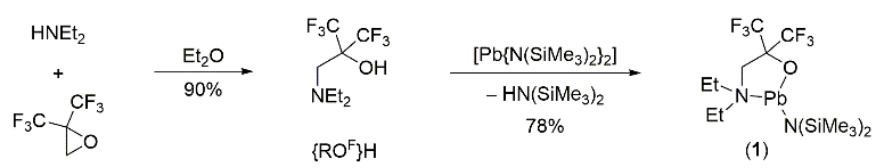

Scheme 1. Synthesis of $2-\mathrm{Et}_{2} \mathrm{NCH}_{2} \mathrm{C}\left(\mathrm{CF}_{3}\right)_{2} \mathrm{OH}\left(\left\{\mathrm{RO} \mathrm{F}^{\mathrm{F}}\right\}\right)$ and $\left[\left\{\mathrm{RO}^{\mathrm{F}}\right\} \mathrm{PbN}\left(\mathrm{SiMe}_{3}\right)_{2}\right](\mathbf{1})$. 


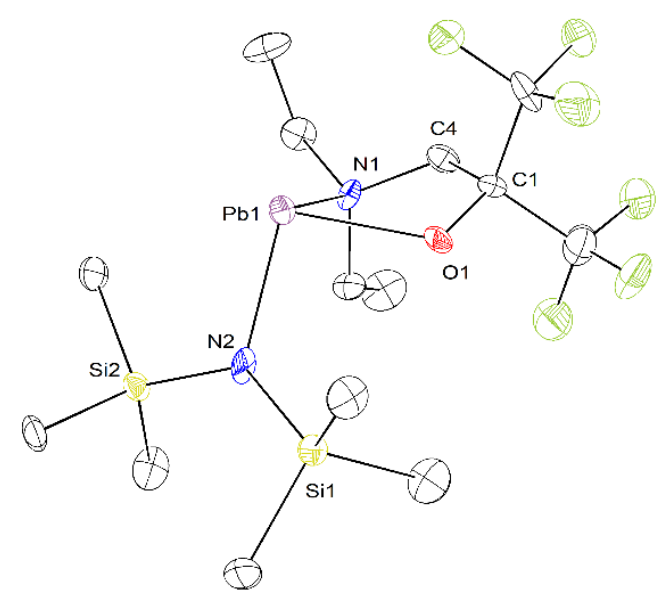

Figure 1. ORTEP view of the molecular solid-state structure of $\left[\left\{\mathrm{RO}^{\mathrm{F}}\right\} \mathrm{PbN}\left(\mathrm{SiMe}_{3}\right)_{2}\right](\mathbf{1})$ Ellipsoids at the $50 \%$ probability level. $\mathrm{H}$ atoms omitted for clarity. Representative bond lengths $(\AA \AA)$ and angles $\left({ }^{\circ}\right)$ : Pb1-O1 = 2.194(7), Pb1-N2 = 2.212(10), Pb1-N1 = 2.550(8), 01 $\mathrm{Pb} 1-\mathrm{N} 2=93.30(3), \mathrm{O} 1-\mathrm{Pb} 1-\mathrm{N} 1=70.70(3), \mathrm{N} 2-\mathrm{Pb} 1-\mathrm{N} 1=100.10(3)$. Torsion angle $\left({ }^{\circ}\right)$ : N1C4-C1-O1 $=-1.50(10)$.

analysis were grown from a concentrated solution in $\mathrm{Et}_{2} \mathrm{O}$ stored at $-43^{\circ} \mathrm{C}$. The identity and purity of the complex were supported by NMR data recorded in benzene- $d_{6}$. Its ${ }^{19} \mathrm{~F}$ NMR spectrum is characterised by a singlet at $\delta_{19 \mathrm{~F}}-76.6 \mathrm{ppm}$, with satellites due to through-space coupling with the central lead atom $\left({ }^{4} J_{\mathrm{PbF}}=161 \mathrm{~Hz}\right)$. The presence of traces of the homoleptic $\left[\left\{\mathrm{RO}^{\mathrm{F}}\right\}_{2} \mathrm{~Pb}\right]\left(2 ; \delta_{19 \mathrm{~F}}-77.1 \mathrm{ppm}\right.$, see below $)$ and $\left[\mathrm{Pb}\left\{\mathrm{N}\left(\mathrm{SiMe}_{3}\right)_{2}\right\}_{2}\right]$ are detected, due to ligand redistribution in solution. The ${ }^{1} \mathrm{H}$ NMR spectrum of 1 shows that the $\mathrm{NCH}_{2} \mathrm{CH}_{3}$ hydrogen atoms are diasterotopic, giving rise to two multiplets of equal intensities centred on $\delta_{1 \mathrm{H}} 2.59$ and $2.49 \mathrm{ppm}$; a single triplet is seen for the $\mathrm{NCH}_{2} \mathrm{CH}_{3} \mathrm{H}$-atoms. High temperature ${ }^{1} \mathrm{H}$ and ${ }^{19} \mathrm{~F}$ VT NMR in toluene- $d_{8}$ indicated that $\mathbf{1}$ is not stable in solution upon increasing the temperature, and that it generates increasing amounts of $\mathbf{2}$ and $\left[\mathrm{Pb}\left\{\mathrm{N}\left(\mathrm{SiMe}_{3}\right)_{2}\right\}_{2}\right]$ due to deleterious ligand scrambling. The ${ }^{207} \mathrm{~Pb}$ and ${ }^{29} \mathrm{Si}$ NMR spectra of $1\left(25^{\circ} \mathrm{C}\right.$, benzene$d_{6}$ ) each contains a single, well-resolved resonance, at respectively $\delta_{207 \mathrm{pb}} 2619 \mathrm{ppm}$ and $\delta_{29 \mathrm{Si}}-3.64 \mathrm{ppm}$. In particular, the ${ }^{207} \mathrm{~Pb}$ resonance is very deshielded compared to that in the dimer $\left[\mathrm{Pb}\left\{\mathrm{OC}(\mathrm{Me})_{2} \mathrm{CH}_{2} \mathrm{SeC}_{6} \mathrm{H}_{4}\left(\mathrm{CH}_{2} \mathrm{NMe}_{2}\right)-2\right\} \mathrm{N}\left(\mathrm{SiMe}_{3}\right)_{2}\right]_{2} \quad(2124$ $\mathrm{ppm}){ }^{16}$ but it is comparable to that in $\left[\mathrm{Pb}\left(\mu_{2}-\mathrm{OR}\right) \mathrm{N}\left(\mathrm{SiMe}_{3}\right)_{2}\right]_{2}$ $(2531 \mathrm{ppm})^{29}$ and in the organolead(II) amide [\{2$\left.\mathrm{Me}_{2} \mathrm{NCH}_{2} \mathrm{C}_{6} \mathrm{H}\right\} \mathrm{PbN}\left(\mathrm{SiMe}_{3}\right)_{2}$ ] (2595 ppm). ${ }^{17,32}$ The ${ }^{1} \mathrm{H}-{ }^{19} \mathrm{~F}$ HOESY NMR spectrum $\left(25{ }^{\circ} \mathrm{C}\right)$ indicates through-space $\mathrm{H} \cdots \mathrm{F}$ interactions between $\mathrm{NCH}_{2} \mathrm{C}\left(\mathrm{CF}_{3}\right)_{2}$ and $\mathrm{CF}_{3}$ atoms.

The molecular solid-state structure of $\mathbf{1}$ is depicted in Figure 1. It shows the lead(II) atom to rest in a three-coordinate environment featuring a distorted trigonal pyramidal geometry. The Pb1-N1 and Pb1-N2 interatomic distances (2.550(8) and 2.212(10) $\AA$ ) are commensurate with those measured in [ $\{2$ $\left.\left.\mathrm{Me}_{2} \mathrm{NCH}_{2} \mathrm{C}_{6} \mathrm{H}\right\} \mathrm{PbN}\left(\mathrm{SiMe}_{3}\right)_{2}\right]$ (2.490(3) and 2.249(3) $\AA$ ); the distance to the amide is noticeably shorter than that to the amine. The three angles around the metal deviate substantially from the ideal $90^{\circ}$ expected for three-coordinate lead(II) centres with $6 s^{2}$ electrons, hence indicating some contribution of the empty $p_{z}$ orbital to the lone pair of electrons in $\mathbf{1}$. This is reflected by the high value (107\%) of the degree of

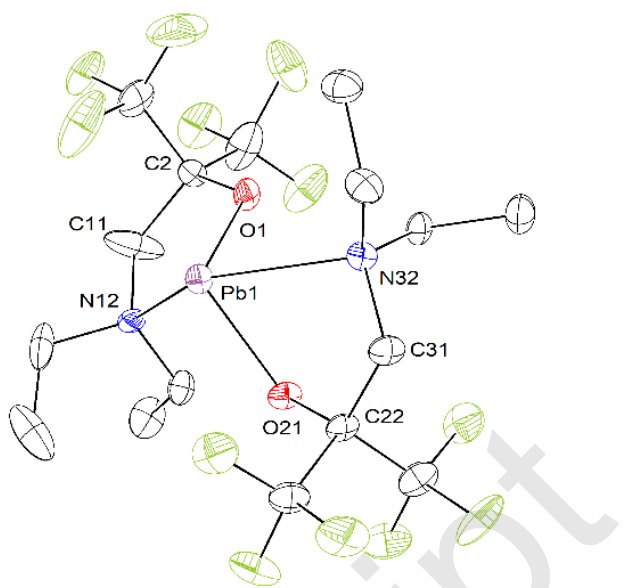

Figure 2. ORTEP representation of the molecular solid-state structure of $\left[\{R O F\}_{2} \mathrm{~Pb}\right](\mathbf{2})$. Ellipsoids at the $50 \%$ probability level. $\mathrm{H}$ atoms omitted for clarity. Only one site occupancy for the disordered $\mathrm{CF}_{3}$ group is depicted. Representative bond lengths $(\AA)$ and angles $\left({ }^{\circ}\right)$ : $\mathrm{Pb} 1-\mathrm{O} 1=2.185(3), \mathrm{Pb} 1-\mathrm{O} 21=2.214(3), \mathrm{Pb} 1-\mathrm{N} 32=2.572(4), \mathrm{Pb} 1-\mathrm{N} 12=$ 2.608(4); O1-Pb1-O21 = 98.34(13), O1-Pb1-N32 = 83.81(12), O21-Pb1-N32 = 68.99(13), O1-Pb1-N12 = 69.90(13), O21-Pb1-N12 = 82.82(13), N32-Pb1-N12 = 138.08(13). Torsion angles $\left({ }^{\circ}\right)$ : O1-C2-C11-N12 = 11.50(9), O21-C22-C31-N32 = -7.30(6)

pyramidalisation (DoP) in 1, ${ }^{33}$ where DoP $=\left[360-\sum_{i=1}^{3} \theta(\mathrm{i})\right] /$ 0.9 and where $\theta(i)$ are the angles around the metal (sum of angles $=264^{\circ}$ ). This value is in particular much greater than that in the $\beta$-diketiminate complex $\left[\left\{\left.\mathrm{BDI}\right|^{\mathrm{DiPP} 2}\right\} \mathrm{PbN}\left(\mathrm{SiMe}_{3}\right)_{2}\right](\mathrm{DiPP}=$ $\left.2,6-i \mathrm{Pr}_{2}-\mathrm{C}_{6} \mathrm{H}_{3}\right)$, that is, $78 \% .^{3}$ It matches those in [ $\left.\left\{\left.\mathrm{BD}\right|^{\mathrm{DiPP} 2}\right\} \mathrm{PbCl}\right]$ $(110 \%)^{10}$ and in the iminoanilide lead(II) chloride $\left[\left\{\mathrm{N}^{\wedge} \mathrm{N}\right\} \mathrm{PbCl}\right]$ (111\%). ${ }^{34}$ The solid-state structure of $\mathbf{1}$ features four short $\mathrm{H} \cdots \mathrm{F}$ interatomic distances involving the $\mathrm{H}$ atoms on $\mathrm{C} 4$. They are in the range $2.460(8)-2.518(8) \AA$, i.e. below the sum of Van der Waals radii for $\mathrm{H}$ and $\mathrm{F}$ (1.09 and $1.47 \AA$ ); these measurements indicate mild interactions and are consistent with the results of ${ }^{1} \mathrm{H}-{ }^{19} \mathrm{~F}$ HOESY NMR analysis in solution.

As mentioned, complex 1 decomposes in solution to return the homoleptic 2 and $\left[\mathrm{Pb}\left\{\mathrm{N}\left(\mathrm{SiMe}_{3}\right)_{2}\right\}_{2}\right]\left(K_{\text {eq }}=4.010^{-2}\right.$ at $25^{\circ} \mathrm{C}$ in benzene- $\left.d_{6}\right)$. The colourless 2 was otherwise prepared in $97 \%$ yield by reacting $\left[\mathrm{Pb}\left\{\mathrm{N}\left(\mathrm{SiMe}_{3}\right)_{2}\right\}_{2}\right]$ with two equivalents of $\left\{R O^{F}\right\} \mathrm{H}$. It is characterised by resonances at $\delta_{207 \mathrm{pb}} 1187 \mathrm{ppm}$ and $\delta_{19 \mathrm{~F}}-77.1 \mathrm{ppm}$ (broad singlet at $25^{\circ} \mathrm{C}$, showing the equivalence of all $\mathrm{CF}_{3}$ substituents on the NMR timescale) by ${ }^{207} \mathrm{~Pb}$ and ${ }^{19} \mathrm{~F}$ NMR spectroscopies in benzene- $d_{6}$. The molecular structure of complex was established by XRD methods (Figure 2 ). It shows a four-coordinate metal in a hemi-directed tetrahedral geometry. ${ }^{35}$ The $\mathrm{Pb}-\mathrm{O}$ and $\mathrm{Pb}-\mathrm{N}$ interatomic distances in $\mathbf{2}$ are similar to those in $\mathbf{1}$.

Complex 1 reacted cleanly with a stoichiometric amount of the borinic acid $\left\{\left(\mathrm{Me}_{3} \mathrm{Si}\right)_{2} \mathrm{CH}\right\}_{2} \mathrm{BOH}$ to produce the heteroleptic $\left[\left\{\mathrm{RO}^{\mathrm{F}}\right\} \mathrm{PbOB}\left\{\mathrm{CH}\left(\mathrm{SiMe}_{3}\right)_{2}\right\}_{2}\right](3)$ in quantitative and reproducible yields (Scheme 2 ). Complex $\mathbf{3}$, a colourless solid that melts at

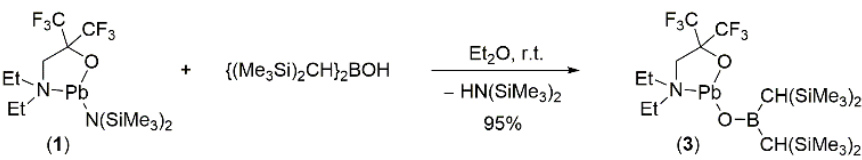

$$
\begin{aligned}
& \text { (1) }
\end{aligned}
$$

Scheme 2. Synthesis of $\left[\left\{\mathrm{RO}^{\mathrm{F}}\right\} \mathrm{PbOB}\left\{\mathrm{CH}\left(\mathrm{SiMe}_{3}\right)_{2}\right\}_{2}\right](\mathbf{3})$ 


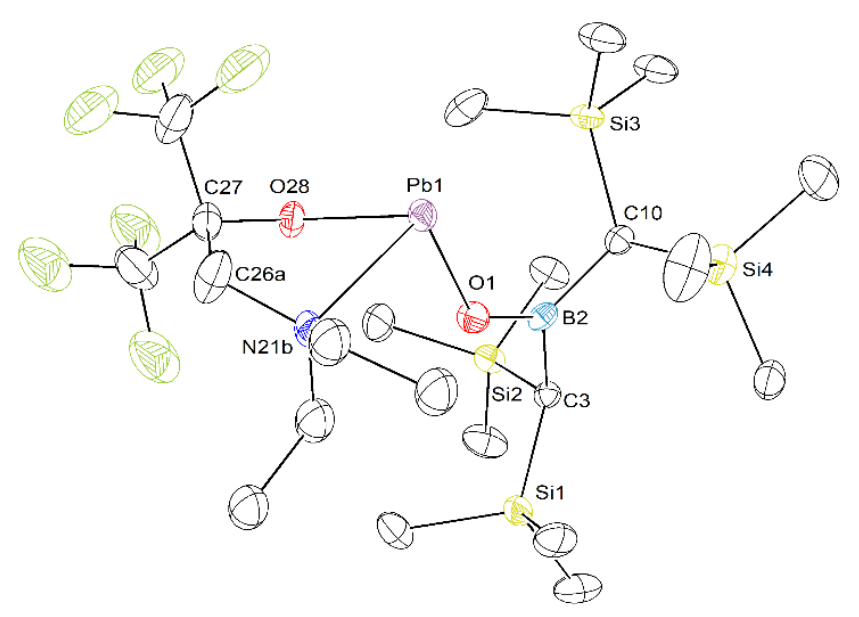

Figure 3. ORTEP representation of the molecular solid-state structure of $\left[\left\{\mathrm{RO}^{\mathrm{F}}\right\} \mathrm{PbOB}\left\{\mathrm{CH}\left(\mathrm{SiMe}_{3}\right)_{2}\right\}_{2}\right]$ (3). Ellipsoids at the $50 \%$ probability level. Only the main component ( $82 \%$ site occupancy) is depicted. $\mathrm{H}$ atoms omitted for clarity. Representative bond lengths $(\AA)$ and angles $\left({ }^{\circ}\right)$ : Pb1-O1 $=2.128(2), \mathrm{Pb} 1-\mathrm{O} 28=2.181(4), \mathrm{Pb} 1-\mathrm{N} 21 \mathrm{~B}=$ $2.448(4)$; O1-Pb1-O28 = 87.25(19), O1-Pb1-N21B = 94.65(12), O28-Pb1-N21B = 71.60(2), $\mathrm{O} 1-\mathrm{B} 2-\mathrm{C} 3=118.20(3), \mathrm{O} 1-\mathrm{B} 2-\mathrm{C} 10=123.40(3), \mathrm{C} 3-\mathrm{B} 2-\mathrm{C} 10=118.40(3), \mathrm{B} 2-\mathrm{O} 1-\mathrm{Pb} 1=$ $132.90(2)$. Torsion angle $\left({ }^{\circ}\right)$ : N21B-C26A-C27-O28 $=-9.50(6)$.

$128^{\circ} \mathrm{C}$ and decomposes irreversibly at $150^{\circ} \mathrm{C}$, is a rare example of stable lead(II) boryloxide. ${ }^{17}$ It exhibits good solubility in most common organic solvents, including hydrocarbons. Colourless single crystals suitable for $\mathrm{X}$-ray diffraction analysis were grown from a concentrated petroleum ether solution stored at $-43^{\circ} \mathrm{C}$ Two sets of analogous site occupancies were found, with one (82\%) far preponderant over the other (18\%); analysis on various sets of single crystals grown from different batches gave identical results. Only the main one of the two components is shown in Figure 3. The geometry around the three-coordinate lead(II) centre is trigonal pyramidal. The DoP is very high (118\%), which illustrates that taken collectively, all angles around the lead atom in $\mathbf{3}$ are narrower than in $\mathbf{1}$ or, even more so, $\beta$ diketiminate lead(II) complexes. ${ }^{3-11}$ The $\mathrm{Pb}-\mathrm{O}_{\text {alkoxide interatomic }}$ distance in 3 (2.181(4) $\AA$ ) is comparable to that in $\mathbf{1}$ (2.194(7) $\AA$ ), but the $\mathrm{Pb}-\mathrm{N}_{\text {amine }}$ is bond length is shorter in 3 than in $\mathbf{1}$ (2.448(4) vs $2.550(8) \AA$ ). This variation is interpreted as the consequences of the low electron-donating ability of the boryloxide compared to the amide. ${ }^{36}$ The $\mathrm{Pb}-\mathrm{O}_{\text {boryloxide }}$ interatomic distance in 3 $(2.128(2) \AA)$ lies between that in the three-coordinate $[\{2$ $\left.\left.\mathrm{Me}_{2} \mathrm{NCH}_{2} \mathrm{C}_{6} \mathrm{H}\right\} \mathrm{PbOB}\left\{\mathrm{CH}\left(\mathrm{SiMe}_{3}\right)_{2}\right\}_{2}\right]$ and the two-coordinate $\left[\mathrm{Pb}\left(\mathrm{OB}\left\{\mathrm{CH}\left(\mathrm{SiMe}_{3}\right)_{2}\right\}_{2}\right)_{2}\right](2.1874(19) \AA$ and 2.067(6)-2.089(5) $\AA$, respectively). ${ }^{17}$ The geometry about the boron atom is trigonal planar $\left(\Sigma_{\theta}(\mathrm{B} 2)=360.0^{\circ}\right)$. The relatively narrow B2-O1-Pb1 angle of $132.90(2)^{\circ}$ suggests only a small p-contribution to the 01$\mathrm{Pb} 1$ bonds. At $1.228 \AA$, the lead atom sits well above the mean plane defined by the near-planar N21B-C26A-C27-028 ligand backbone (torsion angle N21B-C26A-C27-O28 $=-9.50(6)^{\circ}$ ). As in $\mathbf{1}$, the molecular structure of 3 features $\mathrm{H} \cdots \mathrm{F}$ interactions, at interatomic distances in the range 2.439(4)-2.496(2) $\AA$, between fluorine atoms and the hydrogens on the ligand backbone at the C26A position.

The ${ }^{19} \mathrm{~F}$ NMR spectrum of crystalline 3 in benzene- $d_{6}$ exhibits a singlet at $\delta_{19 \mathrm{~F}}-77.1 \mathrm{ppm}$, and satellites owing to coupling with the metal $\left({ }^{4} J_{\mathrm{F}-\mathrm{Pb}}=125 \mathrm{~Hz}\right)$; the presence of traces of $\mathbf{2}$ and an unknown impurity (singlet at $\delta_{19 \mathrm{~F}}-73.2 \mathrm{ppm}$, with satellites presenting a coupling constant of $252 \mathrm{~Hz}$ to a nucleus whose natural abundancy, ca. $30-40 \%$, does not match that of ${ }^{207} \mathrm{~Pb}$, $22.6 \%$; this impurity was also at times detected in variable quantities in the ${ }^{19} \mathrm{~F} \mathrm{NMR}$ data for $\mathbf{1}$ and $\mathbf{2}$ ) is also visible. Compound 3 gives rises to a multiplet at $\delta_{207 \mathrm{pb}} 1425 \mathrm{ppm}\left({ }^{4} J_{\mathrm{Pb}-\mathrm{F}}\right.$ $\approx 125 \mathrm{~Hz}$ matching that determined in the ${ }^{19} \mathrm{~F}$ NMR spectrum) in the ${ }^{207} \mathrm{~Pb}$ NMR spectrum. The ${ }^{11} \mathrm{~B}$ NMR spectrum contains a single, broad resonance at $\delta_{11 \mathrm{~B}} 49.5 \mathrm{ppm}$ diagnostic of this boryloxide, while a sharp singlet is seen at $\delta_{29 \mathrm{si}}-3.49 \mathrm{ppm}$ in the ${ }^{29}$ Si NMR spectrum.

On the whole, complex $\mathbf{3}$ is an unusual example of threecoordinate lead(II) compounds, and is one of the three cases of known Pb-boryloxide. ${ }^{17}$ The complex is stable in the solid state and shows minor formation of homoleptic species upon ligand scrambling in solution (see above). Its stability is seen as the expression of the chelating bidentate ligand $\left\{\mathrm{RO}^{\mathrm{F}}\right\}^{-}$, but also of the steric protection, and hence the kinetic stability, imparted by the very bulky boryloxide $\left\{\left(\mathrm{Me}_{3} \mathrm{Si}\right)_{2} \mathrm{CH}\right\}_{2} \mathrm{BO}^{-}$. For instance, our attempts to use a different borinic acid, $\left(2,4,6-i \mathrm{Pr}_{3}-\mathrm{C}_{6} \mathrm{H}_{2}\right)_{2} \mathrm{BOH}$, to produce related well-defined, mononuclear $\mathrm{Pb}^{\text {"l-boryloxide }}$ species, were unsuccessful. They instead returned crops of the centrosymmetric oxocluster of composition $\left[\mathrm{Pb}_{4}\left(\mu_{3}-\mathrm{O}\right)_{2}\left\{\mu_{2}-\right.\right.$ $\left.\left.\mathrm{OB}\left(2,4,6-i \mathrm{Pr}_{3}-\mathrm{C}_{6} \mathrm{H}_{2}\right)_{2}\right\}_{4}\right](4)$, as authenticated by XRD analysis (Figure 4). No other compound could be identified from the crude of these reactions, which were not probed further. The uncontrolled formation of this aggregate is reminiscent of that observed for $\mathrm{Pb}^{\mathrm{II}}$-siloxides, e.g. $\left[\mathrm{Pb}_{4}\left(\mu_{4}-\mathrm{O}\right)\left(\mu_{2}-\mathrm{OSiPh}_{3}\right)_{6}\right]$ or $\left[\mathrm{Pb}_{7}\left(\mu_{3}-\mathrm{O}\right)\left(\mu_{4}-\mathrm{O}\right)\left(\mu-\mathrm{OSiMe}_{3}\right)_{10}\right] .{ }^{37-38}$ The molecular structure of 4 shows two distinct lead(II) environments. Both are in a threecoordinate distorted trigonal pyramidal geometry, with DoP = $113 \%$ and $118 \%$ for $\mathrm{Pb} 1$ and $\mathrm{Pb} 2$, together with uneven $\mathrm{Pb}-\mathrm{O}$ interatomic distances. The geometry about the boron atom is trigonal planar $\left(\Sigma_{\theta}(B)=360.0\right.$ and 359.7 for $B 1$ and $\left.B 41\right)$.

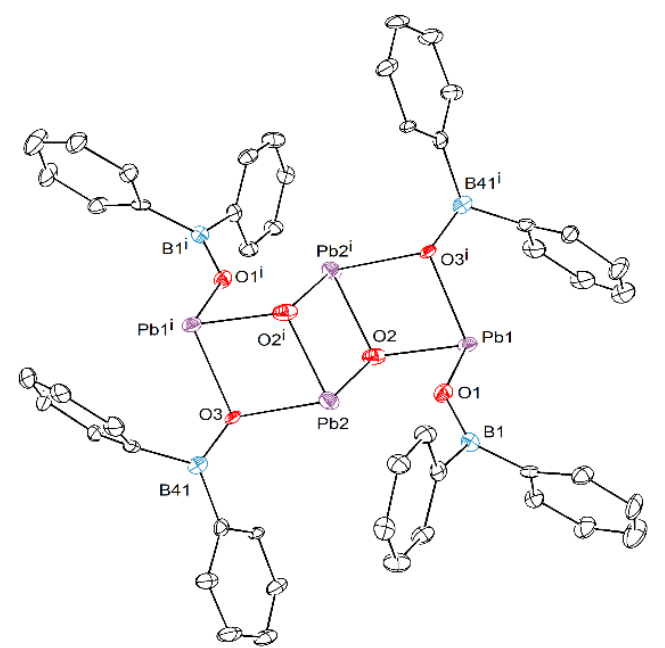

Figure 4. ORTEP representation of the molecular solid-state structure of $\left[\mathrm{Pb}_{4}\left(\mu_{3}-\mathrm{O}\right)_{2}\left\{\mu_{2}\right.\right.$ $\left.\left.\mathrm{OB}\left(2,4,6-i \mathrm{Pr}_{3}-\mathrm{C}_{6} \mathrm{H}_{2}\right)_{2}\right\}_{4}\right]$ (4). Ellipsoids at the $50 \%$ probability level. $\mathrm{H}$ atoms and $\mathrm{Pr}$ groups not represented for clarity. Representative bond lengths $(\AA)$ and angles $\left({ }^{\circ}\right)$ : Pb1$\mathrm{O} 2=2.201(5), \mathrm{Pb} 1-\mathrm{O} 1=2.231(5), \mathrm{Pb} 1-03^{\mathrm{i}}=2.350(5), \mathrm{Pb} 2-\mathrm{O} 2=2.206(5), \mathrm{Pb} 2-\mathrm{O} 2^{\mathrm{i}}=$ $2.231(5), \mathrm{Pb} 2-\mathrm{O} 3=2.437(5) ; \mathrm{O} 2-\mathrm{Pb} 1-\mathrm{O} 1=81.08(18), \mathrm{O}_{2}-\mathrm{Pb} 1-\mathrm{O} 3^{\mathrm{i}}=76.85(17), \mathrm{O} 1-\mathrm{Pb} 1-$ $\mathrm{O}^{\mathrm{i}}=100.50(17), 02-\mathrm{Pb} 2-02^{\mathrm{i}}=77.70(2), \mathrm{O} 2-\mathrm{Pb} 2-\mathrm{O} 3=102.02(17), \mathrm{O}^{\mathrm{i}}-\mathrm{Pb} 2-\mathrm{O} 3=$ 74.52(17). Symmetry transformations used to generate equivalent atoms: $-x,-y,-z$. 


\section{Conclusions}

In summary, the readily available fluoroalkoxide $\left\{R O^{F}\right\}^{-}$enables the high-yield syntheses of three-coordinate heteroleptic lead(II) alkoxides. The amido complex $\mathbf{1}$ is a convenient entry point into further organometallic and inorganic chemistry of these species, as illustrated by the preparation of the boryloxide 3, a new addition to the limited set of discrete $\mathrm{Pb}^{\text {"-alkoxide }}$ currently available. Not all boryloxide are suited to lead(II) chemistry, as exemplified by the uncontrolled formation of the oxocluster 4. We are currently further exploring the potential offered by the ligand core $\left\{R O^{F}\right\}^{-}$in this chemistry and will communicate on these results in a forthcoming report.

\section{Conflicts of interest}

There are no conflicts to declare.

\section{Notes and references}

$¥$ Dedicated to the $100^{\text {th }}$ anniversary of the founding of a Romanian University in Cluj-Napoca, Romania. We thank the University of Rennes for an incoming research grant to A.-A.S.

1 H. Sigel, C. P. Da Costa and R. B. Martin. Coord. Chem. Rev., 2001, 219-221, 435.

2 For a review, see: J. Parr., Polyhedron, 1997, 16, 436.

3 M. Chen, J. R. Fulton, P. B. Hitchcock, N. C. Johnstone, M. F. Lappert and A. V. Protchenko, Dalton Trans., 2007, 2770.

4 J. R. Fulton, P. B. Hitchcock, N. C. Johnstone and E. C. Y. Tam, Dalton Trans., 2007, 3360.

5 E. C. Y. Tam, N. C. Johnstone, L. Ferro, P. B. Hitchcock and J. R. Fulton, Inorg. Chem., 2009, 48, 8971.

6 M. J. Taylor, A. J. Saunders, M. P. Coles and J. R. Fulton, Organometallics, 2011, 30, 1334.

7 E. C. Y. Tam, N. A. Maynard, D. C. Apperley, J. D. Smith, M. P. Coles and J. R. Fulton, Inorg. Chem., 2012, 51, 9403.

8 L. A.-M. Harris, E. C. Y. Tam, M. P. Coles and J. R. Fulton, Dalton Trans., 2014, 43, 13803.

9 M. J. Taylor, E. J. Coakley, M. P. Coles, H. Cox and J. R. Fulton, Organometallics, 2015, 34, 2515.

10 E. C. Y. Tam, M. P. Coles, J. D. Smith and J. R. Fulton, Polyhedron, 2015, 85, 284

11 E. C. Y. Tam, D. C. Apperley, J. D. Smith, M. P. Coles and J. R. Fulton, Inorg. Chem., 2017, 56, 14831.

12 S. Yao, S. Block, M. Brym and M. Driess, Chem. Commun., 2007, 3844.

13 A. Jana, S. Pillai Sarish, H. W. Roesky, C. Schulzke, Al. Döring and M. John, Organometallics, 2009, 28, 2563.

14 A. Jana, S. Pillai Sarish, H. W. Roesky, D. Leusser, I. Objartel and D. Stalke, Chem. Commun., 2011, 47, 5434.

15 R. Olejník, Z. Padělková, R. Mundil, J. Merna and A. Růžička, Appl. Organometal. Chem., 2014, 28, 405.

16 A. Pop, L. Wang, V. Dorcet, T. Roisnel, J.-F. Carpentier, A. Silvestru and Y. Sarazin, Dalton Trans., 2014, 43, 16459.

17 A.-A. Someşan, E. Le Coz, T. Roisnel, C. Silvestru and Y. Sarazin, Chem. Commun., 2018, 54, 5299.

18 L. Pu, B. Twamley and P. P. Power, J. Am. Chem. Soc., 2000, 122, 3524.

19 For a review: P. P. Power, Organometallics, 2007, 26, 4362.

20 J. Schneider, C. P. Sindlinger, K. Eichele, H. Schubert and L. Wesemann, J. Am. Chem. Soc., 2017, 139, 6542.

21 H. Vaňkátová, L. Broeckaert, F. De Proft, R. Olejník, J. Turek, Z. Padělková and A. Růžička, Inorg. Chem., 2011, 50, 9454.
22 L. Wang, S.-C. Roşca, V. Poirier, S. Sinbandhit, V. Dorcet, T. Roisnel, J.-F. Carpentier and Y. Sarazin, Dalton Trans., 2014, 43, 4268.

23 B. D. Rekken, T. M. Brown, M. M. Olmstead, J. C. Fettinger, and P. P. Power, Inorg. Chem., 2013, 52, 3054.

24 A. Stasch, C. M. Forsyth, C. Jones and P. C. Junk, New J. Chem. 2008, 32, 829.

25 J. Li, A. Stasch, C. Schenk and C. Jones, D. Trans., 2011, 40, 10448.

26 V. Zaitsev, V. S. Cherepakhin, A. V. Churakov, A. S. Peregudov, B. N. Tarasevich, M. P. Egorov, G. S. Zaitseva and S. S. Karlov, Inorg. Chim. Acta, 2016, 443, 91.

27 S. C. Goel, M. Y. Chiang and W. E. Buhro, Inorg. Chem., 1990, 29, 4640 .

28 C. S. Weinert, I. A. Guzei, A. L. Rheingold and L. R. Sita, Organometallics, 1998, 17, 498.

29 L. Wang, S. Fadlallah, C. Bellini, C. Orione, V. Dorcet, J.-F. Carpentier and Y. Sarazin, Organometallics, 2015, 34, 1321.

30 J.-F. Carpentier, Dalton Trans., 2010, 39, 37.

31 V. A. Petrov, Synthesis, 2002, 15, 2225.

32 For ${ }^{207} \mathrm{~Pb}$ NMR chemical shifts, see: B. Wrackmeyer, Annu. Rep. NMR Spectrosc., 2002, 47, 1.

33 Z. B. Maksić and B. Kovačević, J. Chem. Soc. Perkin Trans. 2, 1999, 2623.

34 C. Bellini, J.-F. Carpentier, V. Dorcet, A. Silvestru and Y. Sarazin, Main Group Met. Chem., 2017, 40, 73.

35 L. Shimoni-Livny, J. P. Glusker and C. W. Bock, Inorg. Chem., 1998, 37, 1853.

36 E. Le Coz, V. Dorcet, T. Roisnel, S. Tobisch, J.-F. Carpentier and Y. Sarazin, Angew. Chem. Int. Ed., 2018, 57, 11747.

37 C. Gaffney, P. G. Harrison and T. J. King, J. Chem. Soc., Chem. Commun., 1980, 1251.

38 C. S. Weinert, I. A. Guzei, A. L. Rheingold and L. R. Sita, Organometallics, 1998, 17, 498. 